\title{
EFFICIENCY OF INTELLECTUAL POTENTIAL AS A FACTOR OF INCREASING THE COMPETITIVENESS OF THE NATIONAL ECONOMY
}

\author{
Pavlo Fisunenko ${ }^{1}$, Andriy Ziuzia²
}

\begin{abstract}
The transformations of the world economy related to the informatization of society, digitalization of the world in the conditions of the COVID-19 pandemic, which created the preconditions for the special urgency of the problem of effective use of the intellectual potential of national economies, have been considered. It has been proved that the determining factor of innovative development and competitiveness of the national economy is the intellectual potential of all levels of the socio-economic system, including the regional level, which generate technological innovations and create opportunities for the country's transition to a higher level of technological paradigm, which becomes a decisive factor in the competitiveness of the national economy. The interaction and mutual influence of potentials in the composition of the economic potential of the region, the impact of IP of certain regions on the national economy (on the example of the Prydniprovsk region) have been revealed. The main factors of competitiveness of the national economy have been analyzed and the development of education and science, equipment and technologies, scientific and technical potential as a basis for effective use of IP of regions has been highlighted. The relationship of intellectual potential, both with the geopolitical situation of the region and the current labor market as well as with the scientific and technical potential of the territory, the number of scientific and educational institutions and their development, the presence of regional scientific clusters have been outlined. The ways of effective use of IP on the basis of the analysis of various directions of conceptual and strategic character of development of national economy have been outlined. The connection between the effective use of intellectual potential and the «retention of talents» and human capital as the main asset of the modern knowledge economy has been studied. It has been concluded that the formation and implementation of the mechanism of retention, cultivation and motivation of staff with modern organizational skills, new digital skills, changing competencies, skills and behavior more in line with Industry 4.0, will depend on the efficiency of intellectual potential and competitiveness of the national economy, to ensure which, the formation and introduction of an innovative ecosystem as a driving force of accelerated economic growth, which is possible through the effective use of intellectual potential is crucial.
\end{abstract}

Key words: intellectual potential, efficiency, Industry 4.0, competitiveness, national economy

JEL Classification: H52, 129, 018, O39

\section{Introduction}

The development of modern society at the stage of knowledge and digital economy, as never before, determines its direct dependence on the effective use of intellectual potential (IP), which is one of the most important factors of innovative development of the country and the main factor of national economy competitiveness among world economies. In the conditions of intellectual, digital economy, the scientific problem of formation and effective use of IP at all levels of social and economic system is essential for innovative development of the country, including the level of separate territories (regions) in which technological innovations are generated and opportunities for the country's transition to a higher level of techno-economic paradigm are created, which becomes a decisive factor in the competitiveness of the national economy.

\footnotetext{
Corresponding author

${ }^{1}$ Prydniprovska State Academy of Civil Engineering and Architecture, Ukraine.

E-mail: fisunenko.pavlo@pgasa.dp.ua

ORCID: https://orcid.org/0000-0002-1339-5860

${ }^{2}$ Prydniprovska State Academy of Civil Engineering and Architecture, Ukraine.

E-mail: kapriz2495@gmail.com

ORCID: https://orcid.org/0000-0003-3519-0476
} 
Scientists' attention to the problem of IP is also explained by its special role in the digitalization of the economy in connection with the beginning of the Fourth Industrial Revolution and the transition to Industry 4.0. The COVID-19 pandemic has greatly accelerated the process of digitalization of national economies the world, giving even greater relevance to this problem.

The peculiarities of IP were investigated by foreign and domestic scientists, in particular: Krasnokutskaya N. S., Volikov V. V., Semikina M. V., Moiseenko I. P., Babiy P. S., Demyanchuk M. A. Aspects of management, assessment and modeling of intellectual potential as well as the impact of digitalization on IP, etc., have been considered in the studies of these scientists. But in the context of radical transfor-mations in the economy associated with the world digitalization and the COVID-19 pandemic, there is a need of thorough scientific generalizations on the category of «intellectual potential», a comprehensive analysis of the impact of IP at all levels, including regional, on the national economy and research of its effective use.

The aim of the study is to consider IP as an important factor in increasing the competitiveness of Ukraine's economy at the meso-level hierarchy of the economic system, study of the impact on the national economy of IP of certain regions (on the example of the Prydniprovsk region), interaction and mutual influence of potentials as a part of economic potential of the region, outlining ways of effective use of IP based on the analysis of different areas of development of the conceptual and strategic nature of the national economy.

Intellectual potential, as an economic category, is considered in the scientific literature according to different scientific approaches (resource, functional, effective). Scientific approaches to the assessment of IP reflect the ability of certain resources of the economic system (including the functional capacity of intellectual resources) to perform its tasks and achieve the goal - through effective use of IP at all levels of the economic system in order to increase the competitiveness of the national economy.

Exploring the intellectual potential in order to outline ways of its effective use in the national economy, it is necessary to take into account the synergistic interac-tion of all its levels, according to the existing hierarchy of the economic system, from personal level - IP of individual, micro- level - IP of the business entity to the mesolevel - IP of a separate territorial unit (region), macro-level - IP of the national economy (state), as well as intellectual potential at the global level (IP of humanity) (Babiy, 2016). Given each of these levels of IP, special attention in the scientific lit-erature is paid to the potential of regions as well as to its role in the innovative development of the national economy. The importance of meso-level of IP for competitive advantages ' creation at the macro-level is due to the fact that the process of creating new knowledge is concentrated in the regions, and it is here on the basis of appropriate infrastructure for its dissemination and application relationships between participants in the innovation process are formed. The intellectual potential of the region (on the example of Dnipropetrovsk region) as «an open system characterized by interaction with the external environment that affects the efficiency of its use in the national economy $\gg$ has already been analyzed by the authors in previous studies. It can be concluded that the IP of any region $\ll \ldots$ in the framework of interaction with the socio-economic potential of Ukraine reflects the state of the territorial socio-economic system» (Fisunenko, Zyuzya, 2019).

\section{Multidimensionality of the category «intellectual potential»}

The processes of formation, management and effective use of IP in the national economy reflects the multifaceted category of «intellectual potential», interdependence with other forms of economic potential-labor (human), technological, informational, organizational, investment and innovation. The most interconnected forms of potential are intellectual and innovative: «Interacting with other forms of potential, including innovation, based on the development of regional economies, intellectual potential focuses on future development and is a complex dynamic system of generating, accumulating and transforming scientific ideas into scientific and technical results, innovative products and processes» (Fisunenko, Zyuzya, 2019). The properties of IP as an open system and the interaction of different forms of potential are confirmed by statistical and scientific data on the economic potential of the Prydniprovsk region.

Dnipropetrovsk region, as one of the leading regions of Ukraine, has a signifi-cant economic potential, developing on the natural potential, 
has a strong industrial potential, which is characterized by a high development level of heavy industry. There are about 500 large and medium-sized industrial enterprises in the region of almost all forms of major economic activities and $18.3 \%$ (UAH 454.1 billion) of all sold industrial products of Ukraine are produced. According to this indicator, the region ranks first in Ukraine. «Its contribution to the gross regional product of the state is more than $10 \%$ and largely determines the general situation in the country» (Investment Passport of Dnipropetrovsk region, 2019). Dnipropetrovsk region is also one of the most investment-attractive regions of Ukraine. Foreign direct investment in the region comes from 57 countries in 914 companies, 11 cities and 18 districts of the region (Strategy of regional development of Dnipropetrovsk region for the period up to 2027, 2020). Its high investment potential is closely related to intellectual potential, because, among the factors of its investment attractiveness (traditions of industrial production, the presence of extensive industrial and transport infrastructure), the most important factor is the high quality of human capital.

Given the labor (human) resources, as the basis of any form of potential, to assess the effectiveness of IP the indicators of the economically active population are important. 1.5 million people (8.5\%) of the economically active population are con-centrated in Dnipropetrovsk region, it is one of the main labor markets and ranks second among the regions of Ukraine in terms of employment of the working age population. The Human Development Index (HDI) is 0.81, and the region's GDP is $\$ 12.5$ billion, which is $11 \%$ of Ukraine's GDP. GDP per capita is $\$ 2,640$. (Investment passport of Dnipropetrovsk region, 2019). Understanding that the effectiveness of the use of IP and other related forms of potential depends on the efficient use of human resources, it is necessary to consider research on the effectiveness of labor potential. Cherep A. V., Dashko I. M., believe that «...the effectiveness of labor potential is determined based on the goals as a function of the results achieved and resources spent on it», and interpret the effectiveness of its use as «...the ratio of the result that characterizes the degree of achievement of the goal (economic, social) to the quantity and quality of the realized abilities of the staff with its achievements» (Cherep, Dashko, 2012).

\section{Intellectual resources and human capital as a basis for the development of intellectual potential}

From the standpoint of IP, it should be noted that the category of «labor re-sources $\gg$ is characterized by a wider coverage of human resources, compared to the categories of «intellectual resources» and «human capital». At the present stage of development of intellectual economy first of all it is necessary to consider ability of the staff to use knowledge and skills, competence and level of qualification for achievement of the set purpose not so much from a position of labor human resources, but from a position of intellectual human resources and the human capital formed on its basis. If in the assessment of the effectiveness of «labor potential» quantitative indicators of performance are dominated, in a comprehensive assessment of IP, along with quantitative, the most important role is played by qualitative indicators of results related to the quality of intellectual human resources and human capital. In The Strategy of Regional Development of Dnipropetrovsk region for the period up to 2027, among the main (basic) competitive advantages of the region according to the results of expert assessment, along with high industrial potential, convenient geographical location and natural resources, unique human resources (3rd place) and intellectual potential of the region (5th place) are noted (Strategy of regional development of Dnipropetrovsk region for the period up to 2027,2020 ).

Among the main factors of competitiveness of the national economy the development of education and science, technology, scientific and technical potential is extremely important based on the effective use of IP of the regions. Scholars note the close relationship of intellectual potential not only with the geopolitical situation of the region, but also with the scientific and technical potential of the territory, «...the density of scientific and educational institutions, social traditions, family composition, and the labor market. The intellectual potential of the territory is formed due to the development of educational institutions of all levels, the introduction of regional educational Internet portals and projects that take into account the specifics of the region, $\langle\ldots\rangle$ development of regional scientific clusters... » (Demyanchuk, 2020). Accordingly, the Dnipro region was and remains one of the leading academic centers of Ukraine, where there are 24 institutions 
of higher education (universities, academies, institutes), which enroll more than 94 thousand students. The scientific and technical potential of the region includes: 55 research institutes, 21 design organizations, Prydniprovsky Scientific Center of the NAS of Ukraine, which employs 4,486 candidates of science, 753 doctors of sciences, 6 corresponding members and 9 academicians of the NAS of Ukraine (Investment Passport of Dnipropetrovsk region, 2019). According to the authors, the scientific activity of higher educational institutions, the Prydniprovsky Scientific Center of the NAS and the Ministry of Education and Science of Ukraine, together with research institutes and design organizations, can be considered as the most important factor in the formation of IP of Dnipropetrovsk region. As it can be seen, Dnipropetrovsk region provides more than 11\% of the country's economy and is an economically developed, investment-attractive region of Ukraine, which also has a strong intellectual potential.

\section{Challenges of the Fourth Industrial Revolution, Industry 4.0 as a factor in the development of intellectual potential}

An important factor in the growth of the competitiveness of the national economy is Ukraine's awareness of the challenges of the Fourth Industrial Revolution and Industry 4.0, which require the rapid involvement of all economic entities in these processes: «Not only developed, but also many developing countries are competing today in the speed and volume of implementation the digitalization of industry, investing heavily in the transition to 4.0» (National Strategy of Industry 4.0, 2018). Given this challenge, the competitiveness of the national economy depends more than ever on the efficient use of IP and is supported by regional policies on Industry 4.0. In 2018, the Dnipro Development Agency together with AIAEU (Association of Industrial Automation Enterprises of Ukraine) and the Dnipro Space Cluster joined the creation of the first regional strategy 4.0 with the support of the Dnipro Regional Council and the City Hall.

Despite some significant results confirming the effectiveness of IP in some re-gions, the competitive position of Ukraine's economy, reflected in world rankings, is quite unstable. A large number of research and higher education institutions, scientists and engineers working at the regional level, and enough a large proportion of people with higher education do not strengthen Ukraine's position in the rankings of «Innovation», «Relations of universities with industry in research and development», «Technological readiness », «Foreign investment and technology transfer», which are quite low. In 2019, Ukraine took 85th place (according to the Executive Opinion Survey: descriptive statistics and weightings), falling to four positions. In 2020, the consolidated ranking of countries according to the Global Competitiveness Index was not presented, but Ukraine's position among other countries in 2021 depends on compliance with conceptual and strategic directions, including the «Strategy for the Development of Innovation Activity until 2030», adopted by the Cabinet of Ministers of Ukraine from July 10, 2019 (Strategy for the Development of Innovation Activity until 2030, 2019).

\section{Strategic directions for improving the efficiency of intellectual potential}

Recently, Ukraine has adopted a number of legislative documents of a conceptual and strategic nature, the implementation of which can contribute to the efficiency of the use of IP and strengthen the competitiveness of Ukraine's economy. Based on the analysis of the Strategy for the Development of Innovation Activity until 2030, and other important conceptual and strategic legislative documents, the authors made scientific summaries of the main program activities and expected results, which are presented in the table (Table 1 ), outlined ways to increase the effectiveness of intellectual capacity competitiveness of both regions and the national economy as a whole.

As it can be seen, according to the World Index of Economic Competitiveness, intellectual potential based on intellectual resources and human capital is recognized as the main asset of the modern knowledge economy, so ways to effectively use intellectual potential are primarily related to the «struggle for talent». It is from the formation and implementation of the mechanism of retention, cultivation and motivation of staff with modern organizational skills, new digital skills, change of competencies, skills and behavior more in line with the requirements of 4.0, from proper talent management will depend on the effectiveness of intellectual potential which will become a «serious barrier to «brainwashing» and loose of engineering personnel in the Ukrainian economy» (National Strategy of Industry 4.0, 2018). To ensure the 
Table 1

Ways to effective use of intellectual potential as a factor in ensuring the competitiveness and innovative development of the national economy

\begin{tabular}{|c|c|c|}
\hline $\begin{array}{l}\text { Conceptual and strategic } \\
\text { legislative documents }\end{array}$ & Basic program activities & Expected results \\
\hline $\begin{array}{l}\text { Strategy for the } \\
\text { development of } \\
\text { innovation activity } \\
\text { until } 2030\end{array}$ & $\begin{array}{l}\text { - Creating a favorable regulatory framework } \\
\text { for business entities engaged in innovation } \\
\text { activity. } \\
\text { - Implementation of innovations and creation } \\
\text { of favorable conditions for bringing innovations } \\
\text { to commercial use, in particular through the } \\
\text { development of startups. } \\
\text { - Development of innovation infrastructure and } \\
\text { methodological and consulting support. } \\
\text { - Expanding the ties of domestic scientists and } \\
\text { inventors with foreign companies. } \\
\text { - Increasing the level of capacity, which is } \\
\text { realized through cultural and educational } \\
\text { activties. } \\
\text { - Enhancing innovation culture through } \\
\text { educational activities aimed at ensuring } \\
\text { a successful career for young people after } \\
\text { graduation from higher education institutions. }\end{array}$ & $\begin{array}{l}\text { - Formation of a national innovation ecosystem } \\
\text { in Ukraine. } \\
\text { - Ensuring the development and effective } \\
\text { interaction of elements of the national } \\
\text { innovation ecosystem. } \\
\text { - Ecosystem as a driver of accelerated economic } \\
\text { growth through the effective use of intellectual } \\
\text { potential. } \\
\text { - Introduction of new technological solutions } \\
\text { based on the ecosystem. } \\
\text { - Approaching Ukraine to the level of } \\
\text { developed countries in the production of } \\
\text { intellectual products and innovations. } \\
\text { - Increasing the country's competitiveness in } \\
\text { the world market. }\end{array}$ \\
\hline $\begin{array}{l}\text { The concept of AIAEU } \\
\text { «Na-tional Strategy of } \\
\text { Industry } 4.0 »\end{array}$ & $\begin{array}{l}\text { Industry } 4.0 \text { is a stage of digital transformation } \\
\text { of industrial enterprises: accelerated } \\
\text { introduction of technologies - industrial } \\
\text { Internet of Things, big data analytics, artificial } \\
\text { intelligence, a new generation of robots, } \\
\text { augmented reality, etc. } \\
\text { - Synergy of IT and OT, change of business } \\
\text { models and significant acceleration of innovative } \\
\text { development. } \\
\text { - Full audit of the structural elements of the } \\
\text { innovation ecosystem } 4.0 \text { (universities, NASU, } \\
\text { parks, design bureaus of state enterprises, etc.), } \\
\text { as the most valuable assets } 4.0 \\
\text { - «Fight for talent», which industrial high-tech } \\
\text { loses to the IT outsourcing and export sectors. } \\
\text { - The «Strategy» framework identifies the } \\
\text { most important organizational skills: new } \\
\text { digital skills, changes in competencies, skills and } \\
\text { behaviors that better meet the requirements of } \\
4.0 \\
\text { - Talent management: talent, according to the } \\
\text { global index of industrial competitiveness, is the } \\
\text { main asset of industrialists. }\end{array}$ & $\begin{array}{l}\text { - Incentive projects are designed to restart } \\
\text { (create) System } 4.0 \text { in Ukraine, the main } \\
\text { purpose of which is development, stimulation } \\
\text { of Industry } 4.0 \text { players, expansion of their } \\
\text { activities and the ecosystem as a whole. } \\
\text { - Launch of incubators of industrial high-tech } \\
\text { segments, as the main condition for integration } \\
\text { into European and world programs and } \\
\text { attracting international investors. } \\
\text { - Incubators of industrial high-tech segments } \\
\text { and Centers } 4.0 \text { should become a serious barrier } \\
\text { to «brainwashing» and engineering personnel } \\
\text { from the economy of Ukraine. } \\
\text { - According to the «Strategy» framework, } \\
\text { all engineers need to know the basics of cloud } \\
\text { technology and communication networks. } \\
\text { - Talent management appeals to developed } \\
\text { policies of recruitment, retention, cultivation } \\
\text { and motivation of staff. }\end{array}$ \\
\hline $\begin{array}{l}\text { «The concept of } \\
\text { development of } \\
\text { digital competencies } \\
\text { and approval of the } \\
\text { action plan for its } \\
\text { implementation» }\end{array}$ & $\begin{array}{l}\text { The main objectives of this Concept are: } \\
\text { formation and development of digital skills } \\
\text { and digital competencies in society, which will } \\
\text { contribute to the development of the digital } \\
\text { economy and society, as well as the development } \\
\text { of e-democracy and human capital. }\end{array}$ & $\begin{array}{l}\text { Implementation of this Concept will allow: } \\
\text { - accelerate the processes of digital } \\
\text { transformation in Ukraine; } \\
\text { - significantly increase the level of digital skills } \\
\text { and digital competencies in society, as well } \\
\text { as the level of state competitiveness and the } \\
\text { quality of human capital; } \\
\text { - increase the competitiveness of employees } \\
\text { by mastering new digital skills and digital } \\
\text { competencies. }\end{array}$ \\
\hline
\end{tabular}


(End of Table 1)

\begin{tabular}{|c|c|c|}
\hline $\begin{array}{l}\text { «Digital Agenda of } \\
\text { Ukraine }-2020 »\end{array}$ & $\begin{array}{l}\text { The main tasks of the «Digital Agenda } \\
\text { of Ukraine» are: } \\
\text { - «Digitalization» as a mechanism (platform) of } \\
\text { economic growth due to increased efficiency and } \\
\text { productivity from the use of digital technologies. } \\
\text { - Effectiveness is achieved through the } \\
\text { possibility of full integration into national } \\
\text { and regional strategies and programs for the } \\
\text { development of any ideas, actions, initiatives } \\
\text { and programs related to «digitalization». } \\
\text { - The key goal is to achieve «digital» } \\
\text { transformation of existing sectors of the economy, } \\
\text { areas of activity, their new quality and properties, } \\
\text { comprehensive «digitalization», which transforms } \\
\text { existing systems and areas into a new value. }\end{array}$ & $\begin{array}{l}\text { The forced digitalization scenario envisages: } \\
\text { - elimination of legislative, institutional, fiscal } \\
\text { and tax, currency and monetary barriers that } \\
\text { hinder the development of innovative economy, } \\
\text { «digitalization»; } \\
\text { - taking strong measures to stimulate the } \\
\text { «digitalization» of the economy and business } \\
\text { sectors; } \\
\text { - initiation by the state of large-scale } \\
\text { transformation initiatives and projects of } \\
\text { «digitalization», including on the basis of } \\
\text { modern models of public-private partnership. }\end{array}$ \\
\hline $\begin{array}{l}\text { The concept of } \\
\text { development of the } \\
\text { National Academy of } \\
\text { Sciences of Ukraine for } \\
2014-2023\end{array}$ & $\begin{array}{l}\text { Notes the existence of a large-scale scientific } \\
\text { complex capable of effectively producing world- } \\
\text { class results and negative trends that need } \\
\text { to be changed if Ukraine wants to develop its } \\
\text { intellectual potential and be competitive among } \\
\text { countries around the world: } \\
\text { - scientific, technical and innovation sphere of } \\
\text { the state as a whole and the National Academy } \\
\text { of Sciences of Ukraine do not properly perform } \\
\text { the role of a source of economic growth; } \\
\text { - scientific results are not used in the economy } \\
\text { due to the low susceptibility of the business } \\
\text { sector to innovation; } \\
\text { - the trend of staff loss and deterioration of } \\
\text { logistics in science, technology and innovation. }\end{array}$ & $\begin{array}{l}\text { Elimination of a number of negative } \\
\text { phenomena as a way to effective use of IP: } \\
\text { - unsatisfactory financing of scientific, technical } \\
\text { and innovative spheres; } \\
\text { - insufficient efficiency of the system of budget } \\
\text { financing of research and development, including } \\
\text { in the institutions of the NAS of Ukraine; } \\
\text { - legislative restrictions that complicate the } \\
\text { commercialization of research results; } \\
\text { - lack of economic incentives for business } \\
\text { entities to carry out technological } \\
\text { modernization through the introduction of new } \\
\text { scientific and technical developments; } \\
\text { - unsatisfactory motivation and stimulation of } \\
\text { scientists in finding partners in the production } \\
\text { sphere and the use of new effective methods of } \\
\text { cooperation; } \\
\text { - shortcomings in the protection, objective } \\
\text { evaluation and use of intellectual property } \\
\text { created at public expense. }\end{array}$ \\
\hline $\begin{array}{l}\text { National strategy in } \\
\text { the field of intellectual } \\
\text { property for the period } \\
2020-2025\end{array}$ & $\begin{array}{l}\text { Determines the creation of the necessary } \\
\text { conditions for the development of IP: } \\
\text { - for the successful completion of legislative, } \\
\text { institutional and judicial reforms in the field of } \\
\text { intellectual property; } \\
\text { - for the creation, protection, management, } \\
\text { commercialization of intellectual property; } \\
\text { - to maximize the potential of intellectual } \\
\text { property in sustainable innovation development; } \\
\text { - creation of an effective system of protection of } \\
\text { intellectual property rights; } \\
\text { - support for the invention; } \\
\text { - raising the level of education and culture } \\
\text { and popularization of knowledge in the } \\
\text { field of intellectual property, which would } \\
\text { generally contribute to the development of a } \\
\text { national competitive digital economy based } \\
\text { on knowledge, innovation and creativity, and } \\
\text { increase its investment attractiveness. }\end{array}$ & $\begin{array}{l}\text { Mechanisms to support innovation, technology } \\
\text { transfer should be implemented, in particular: } \\
\text { - direct financing of innovation and technology } \\
\text { transfer; } \\
\text { - venture financing; } \\
\text { - tax support for innovation; } \\
\text { - lending for innovations; } \\
\text { - support for knowledge transfer; } \\
\text { - support for the commercialization of } \\
\text { intellectual property rights; } \\
\text { - development of innovation infrastructure; } \\
\text { - support of innovative activity at the } \\
\text { enterprises, including public-private } \\
\text { partnership. }\end{array}$ \\
\hline
\end{tabular}

Source: built by the authors 
competitiveness of the national economy, the formation and introduction of an innovative ecosystem as a driving force of accelerated economic growth, which is possible through the effective use of intellectual potential, is also crucial.

\section{Conclusions}

Thus, among the important conceptual and strategic directions of effective use of the intellectual potential of the state and ways to solve this problem, one of the most important is to increase the level of innovation of the national economy to build a national innovation ecosystem, which provides incentive projects to motivate talents, which are the main asset of industrialists, favorable conditions for the development of innovation and increase on this basis the number of implemented developments, increase economic returns from them, attract investment in innovation and create conditions for bringing innovation to commercial use, in particular through the development of startups. The transition to 4.0 technology also depends on the effectiveness of intellectual potential and is possible only with the mobilization of all participants in the ecosystem (including HEI and NASU), priority focus on changing customer culture, developing a culture of innovation - through education, changing the culture of scientists and educators - from self-centered orientation to customer-centric, improving cooperation between ecosystem participants and creating mechanisms to significantly accelerate the transition of scientific developments into a practical phase, focusing on global markets based on the combined potential of HEI and NASU (National Strategy of Industry 4.0, 2018). Important and logically justified are the tasks set by the Concept of Development of the National Academy of Sciences of Ukraine for 2014-2023, such as: $\ll \ldots$ interaction with regional authorities to scientifically ensure the solution of current problems of socio-economic development of relevant regions of Ukraine by involvement of scientists and specialists in this matter, regardless of their departmental subordination $\gg$ (Concept of Development of the National Academy of Sciences of Ukraine for 2014-2023, 2014). The solution to the problem of effective use of intellectual potential associated with the transition of Ukraine from a natural resource economy to a «knowledge economy» will be possible through the rapid digitalization of all spheres of life, transition to Industry 4.0, knowledge capitalization, talent management and use of intelligence that creates products with high added value as the most important factors in the competitiveness of the national economy. The formation and implementation of the mechanism of retention, cultivation and motivation of personnel with modern organizational skills, new digital skills, change of competencies, skills and behavior more in line with the requirements of Industry 4.0 will depend on the efficiency of intellectual potential and competitiveness of the national economy.

\section{References:}

Babij, P. S. (2016). Algorytmy upravlinnja, ocinka ta modeljuvannja intelektua-lnogo potencialu v systemi vyrobnycho-gospodarskoi dijalnosti socialno-ekonomichnyh subjektiv [Algorithms of management, estimation and modeling of intellectual potential in the system of production and economic activity of social and economic subjects]. Regional aspects of development of productive forces of Ukraine, no. 21, pp. 109-113. Available at: http://nbuv.gov.ua/UJRN/rarpsu_2016_21_21 (accessed 10 May 2021).

Demjanchuk, M. A. (2020). Vplyv cyfrovyh transformacij na intelektualnyj potencial pidpryjemstva [Influence of digital transformations on the intellectual potential of the enterprise]. Problems of system approach in economics, vol. 1, no. 75, pp. 98-106.

Fisunenko, P. A., \& Zjuzja, A. O. (2019). Vykorystannja intelektualnogo potencialu Dnipropetrovskoi oblasti u nacionalnij ekonomici [The use of intellectual potential of the Dnipropetrovsk region in the national economy]. Proceedings of the Aktualni problemy vykorystannja potencialu ekonomiky krainy: svitovyj dosvid ta vitchyznjani realii (Ukraine, Dnipro, May 25, 2019). Dnipro: PDABA, pp. 45-49.

Investycijnyj pasport Dnipropetrovskoi oblasti: veb-sajt [Investment passport of Dnipropetrovsk region: website]. Available at: http://dia.dp.gov.ua/ (accessed 12 May 2021).

Cherep, A. V., \& Dashko, I. M. (2012). Metodychni pidhody do ocinky efektyvnosti vykorystannja trudovogo potencialu pidpryjemstv [Methodical approaches to assessing the effectiveness of the use of labor potential of enterprises]. Agrosvit, pp. 48-50.

Strategija rozvytku Industrija 4.0 veb-sajt [National Strategy of Industry 4.0]. Available at: https://mautic.appau.org.ua/asset/40:strategia-rozvitku-4-0-v3-korotkadocx (accessed 12 May 2021). 
Pro shvalennja Strategii rozvytku sfery innovacijnoi dijalnosti na period do 2030 roku [On approval of the Strategy for the development of innovation for the period up to 2030]. Official website of the Verkhovna Rada of Ukraine. Available at: https://zakon.rada.gov.ua/laws/show/526-2019\%D1\%80\#Text (accessed 14 May 2021).

Rozporjadzhennja KMU vid 03 bereznja 2021 r. № 167-r «Pro shvalennja Koncepcii rozvytku cyfrovyh kompetencij ta zatverdzhennja planu zahodiv z ii realizacii» [Order of the Cabinet of Ministers of March 3, 2021 № 167-r «On approval of the Concept of development of digital competencies and approval of the plan of measures for its implementation»]. Official website of the Verkhovna Rada of Ukraine. Available at: https://zakon.rada.gov.ua/laws/show/167-2021-\%D1\%80 (accessed 14 May 2021).

«Cyfrova adzhenda Ukrainy - 2020 («Cyfrovyj porjadok dennyj - 2020») [《Digital Agenda of Ukraine - 2020»]. Available at: https://www.kmu.gov.ua/news/249575382 (accessed 14 May 2021). «Pro zatverdzhennja Derzhavnoi strategii regionalnogo rozvytku na 2021-2027 roky»: Postanova Kabinetu Ministriv Ukrainy vid 05 serpnja 2020 roku № 26953 [ «On approval of the State Strategy for Regional Development for 2021-2027 »: Resolution of the Cabinet of Ministers of Ukraine of August 5, 2020 № 26953]. Official site of the Ministry of Regional Development of Ukraine. Available at: https://www.minregion.gov.ua (accessed 17 May 2021).

«Pro shvalennja Koncepcii rozvytku Nacionalnoi akademii nauk Ukrainy na 2014-2023 roky»: Postanova № 187 vid 25.12.2013 [ $\ll$ On approval of the Concept of Development of the National Academy of Sciences of Ukraine for 2014-2023 >: Resolution № 187 of 25.12.2013]. Presidium of the National Academy of Sciences of Ukraine. Available at: https://zakon.rada.gov.ua/rada/show/v0187550-13\#Text (accessed 17 May 2021).

«Nacionalna strategija u sferi intelektualnoi vlasnosti na period 2020-2025 roky» (proekt) [ National strategy in the field of intellectual property for the period 2020-2025» (project)]. Available at: http://nipo.org.ua/activity/stvorennya-efektivnogo-navchalnogo-centru-u-sferi-intelektualnoivlasnosti-iv (accessed 17 May 2021). 